\title{
Mobile-Assisted Task-Based Language Learning, Writing Competency, And Motivation
}

\author{
Putu Adelina Kartika Dewi*, Ni Made Ratminingsih, Made Hery Santosa \\ English Language Education, Post Graduate Program, Universitas Pendidikan Ganesha, Singaraja, Indonesia \\ e-mail: adelinakartika16@gmail.com, made.ratminingsih@undiksha.ac.id, mhsantosa@undiksha.ac.id
}

\begin{abstract}
This quasi-experimental study aimed at investigating the effect of mobile-assisted task-based learning on students' writing competency and students' motivation in writing. Post-test only control group design was employed in this study. The experimental group was taught by mobile-assisted taskbased learning while the control group was taught by non mobile-assisted task-based learning. $A$ writing post-test and questionnaire were used to obtain the data and were analyzed using one-way ANOVA and MANOVA. The findings of the study revealed that (1) there was a significant effect of Mobile-assisted Task-based Learning on the students' writing competency; (2) there was a significant effect of Mobile-assisted Task-based Learning on the students' writing motivation; and (3) there was a simultaneous effect of Mobile-assisted Task-based Learning on the students' writing competency and students' motivation in writing. This study concluded that the use of mobile devices as a medium in the learning process is effective to enhance the students' writing competency and increase students' motivation in writing.
\end{abstract}

Keywords: Mobile-Assisted Learning; Motivation in Writing; Task-Based Learning; Writing Competency

\section{Introduction}

In learning a language, there are four language skills that should be mastered by the students, namely listening, speaking, reading, and writing. Writing is very important in education as a medium for students to express their ideas, feelings, and thoughts (Gupta \& Woldemariam, 2011). Writing requires the students to focus on the development of the language used while solving problems in writing including generating ideas, planning, and evaluating the writing (Harmer, 2004). In writing activity, the students do not only put words together, but also transform their ideas into written form by using the target language meaningfully (Brown, 2007). Additionally, to support their writing, the students need to master several things, such as the ability to interpret information, formulate ideas, organize ideas, use appropriate grammar, and pay attention to writing mechanics (Listyani, 2018). It is essential to have the ability to write meaningfully as it is used as a means of developing, reinforcing, and testing the communicative ability of the target language, as well as testing the grammar accuracy and vocabulary choices (Reichelt, 2005).

Writing can be said as an activity that focuses on process and product. The process is when the students gathering ideas related to the topic of their writing and the product is the final version of the students' writing that can be read by the readers (Linse \& Nunan, 2005). There are at least three major phases of the writing process, namely pre-writing, during writing, and post-writing (Lincoln \& Idris, 2015). In pre-writing, the students are developing their background knowledge, selecting and narrowing relevant ideas about the topic, brainstorming and organizing ideas. During the writing phase, the students are required to develop the ideas that they have into a paragraph. The last phase is the post-writing phase in which the students focus on revising and editing their writing by following the agreement in terms of the content of the writing, organization of the ideas, grammar, spelling, punctuation, and capitalization. Nevertheless, encouraging the students to have a willingness to write is

\footnotetext{
* Corresponding author.

Received 26 January 2020; Accepted 21 March 2020; Available online 31 March 2020

(c) 2020 JPI. All Rights Reserved
} 
not an easy task (Sundari, Febriyanti, \& Saragih, 2018). In their research, Sundari et al. found that students still face problems in writing as it is a complex activity that requires the students to have good linguistics skills, such as appropriate grammar usage, vocabulary choices, writing mechanics, and also text structure. Besides, the students need to follow several phases to produce a cohesive text. In writing, the students commonly faced some problems such as generating ideas for their writing, using appropriate and suitable vocabularies with the context of their writing due to limited vocabulary, using appropriate grammar that suitable with the genre of the text, transforming the ideas that they have into written text, and connecting paragraphs coherently and cohesively (Listyani, 2018; Ningrum, Latief, \& Sulistyo, 2016). In addition, writing can be said as a challenging activity due to the difference between the target language and the students' native language (Dwivedi, 2015). In the research conducted by Dwivedi (2015), it was found that the students' writing might be grammatically correct but still inappropriate because there was interference from the students' native language in terms of styles, grammar usage, or arrangement of the ideas.

In line with the above-mentioned studies, the eleventh-grade students in a Senior High School in Singaraja also encountered similar problems. Based on the preliminary research, itwas found that the students still experienced several problems in writing activity such as they felt struggled to construct ideas during the writing process. In students' writing, it was found that the students still had problems in terms of organizing ideas, using appropriate grammar for a certain text genre, lack of sentence variety, and insufficient choice of vocabulary.

Apart from the problems encountered by the students, motivation plays an important role in the development of the students' writing and task completion, as it forces the students to write meaningfully (Aprizawati, 2017; Hamidun, Hashim, \& Othman, 2012). Ellis (2003) further argues that the students will easily complete the task given by the teacher when they are motivated to do so. On the other hand, when the students are not motivated, they will need more time than the assigned time to finish the task. Ryan and Deci (2017) add that motivation concerns with what moves the students to take action, or the energy that leads the students to start doing, reach their goal and maintain what they are doing. Students' motivation in writing is affected by several factors, namely self-efficacy belief, writing task value and interest, and goal orientation (Boscolo \& Hidi, 2007; Troia, Shankland, \& Wolbers, 2012). Self-efficacy belief is related to students' belief in their ability in writing, including ideation which means the ability to generate ideas and ordering them, conventions which means the ability to use accepted standards for writing, such as spelling, punctuation, capitalization, and grammar, and self-regulation which means the ability to manage anxiety and emotions that might come during the writing process (Bruning, Dempsey, Kauffman, \& Zumbrunn, 2013). When the students are interested in the activity and the process, they will pay greater attention to every step and aspect and show engagement in every process (Troia et al., 2012). The task itself will make the students have better motivation when the task given is relevant to their needs, when the task presents a challenge, invites curiosity, and important for their life (Troia et al., 2012). The last factor that affects the students' motivation is goal orientation which is related to the students' reason for doing the task, whether it is focused on knowledge, skill attainment or demonstrating relative ability, receiving public recognition, and surpassing others (Troia et al., 2012).

Lately, there are many techniques proposed by the experts in helping the teacher in giving writing instructions that require the students to involve actively in the writing process, and one of them is through implementing task-based learning. This approach provides students with a learning environment focuses on students' experience in performing the task, which relies on the steps involved in the drafting and redrafting writing because it highlights the concept of writing as a process of developing including the meaning interpretation and formulating ideas (Estarki \& Bazyar, 2016). Further, Richards and Rodgers (2001) also argue that task-based language learning is an approach that uses the task as a core unit of analysis, planning, and instruction. In line with this statement, Dost, Bohloulzadeh, and Pazhakh (2017) agree that task-based language learning emphasizes on requiring learners 
to perform meaningful tasks and use the target language without worrying about accuracy and structures.

Based on the previous studies, the implementation of task-based language learning is effective for the students to help them in producing better writing as it gives the students benefits in terms of their writing performance and developing their creativity (Marashi \& Dadari, 2012). Task-based language learning helps the students to improve their writing skills in terms of sentence structure, language use, vocabulary usage, the content of the writing, and the organization of the ideas on the writing (Kafipour, Mahmoudi, \& Khojasteh, 2018; Sundari et al., 2018). Besides, task-based language learning also increases the students' learning motivation which can be seen in students' interest in the writing process, enjoyment, improvement of students' writing performance and the ability in selecting appropriate information (Huang, 2016).

In line with the demands of current developments, advanced learning trends are always followed by the advancement of information and technology, especially in the application of mobile-assisted language learning (Thomas \& Reinders, 2010). Mobile-assisted language learning focuses on the use of mobile technology in language learning, in which the students not merely learn in the classroom, but they also might learn the target language outside the class, when they have an opportunity to learn and when they have a desire to learn the language (Miangah \& Nezarat, 2012). Mobile learning provides modern methods to facilitate the language learning process through the use of mobile devices learning tools such as mobile phones, laptops, PCs and personal digital assistants (Arvanitis, Krystalli, \& Panagiotidis, 2016). Furthermore, the use of mobile devices in language learning may help students to improve their language skills, and one of them is writing skills. Bipinchandra, Puteh, Shah, and Din (2014) found that the ability to write can be developed through mobile learning, as it helps students use it anywhere and at any time, and can help students learn more collaboratively without worrying about time and place in improving their writing skills. Teachers and students might emphasize the writing through online text chatting, taking notes the ideas about a certain topic, followed by sending emails the written text and posting their writing in social media as the target task (Park \& Slater, 2014).

The implementation of a task-based learning approach, supported by the use of mobile phones (mobile-assisted learning) in teaching writing, is a good lesson plan to meet the demands of today's needs, both in terms of material development and strategy. Anwar and Husniah (2016) in their research found that that a task-based approach combined with technology provides a good impact on students' achievement and gives students greater motivation to finish writing. Besides, Ziegler (2016) in his research found that implementing technology-mediated task-based learning promotes the students' motivation, independence, confidence in using the target language, and willingness to communicate. The presence of mobile application in writing activity helps the students to have a better self-editing progress in terms of sentence structure, language use, vocabulary, the content of the writing, the organization of the ideas, as well as the writing mechanics (Kafipour et al., 2018; Li \& Hegelheimer, 2013).

The points of view and the discussions mentioned above support the teaching approach in developing writing skills, highlighting the importance of implementing task-based language learning with the support of mobile (mobile-assisted language learning) in writing skills and motivation of students. In this study, the focus is on the process of the students in completing the task by following the three task-based language learning phases with the support of mobile applications that can help the students in brainstorming their ideas by using online mapping. After that the students need to develop their ideas based on the result of online sharing, then revise and edit their writing by using grammar checker in terms of the sentence structure, grammar, vocabulary, and writing mechanics, which is related to their motivation, especially on the self-efficacy belief. Thus, in all process of writing and completing the task, the students are supported by the applications of mobile devices.

Therefore, the current study aimed at investigating the effect of mobile-assisted taskbased learning on students' writing competency and students' motivation in writing. Besides, 
this study also analyzes the simultaneous effect of mobile-assisted task-based learning on students' writing competency and students' motivation in writing.

\section{Method}

This study was an experimental research that employed Post-test Only Control Group Design. There were two groups involved in this study. The first group was the experimental group which was taught by mobile-assisted task-based learning, and the second group was the control group which was taught by non mobile-assisted task-based learning.

The population of this study was all the eleventh-grade students of a Senior High School in Singaraja in the academic year 2017/2018. A cluster random sampling was conducted in determining the experimental and control group by using a lottery. The comparison of the learning activities for both the experimental and control group are described as follows.

In this study, there were three phases that should be followed by the students of both groups. The first phase was Pre-task phase. In this phase, at first, the teacher introduced the topic and the task. Further, the teacher helped the students to build students' background knowledge related to the topic by brainstorming. The experimental group students were guided to create an online mind map, watch related videos, and read texts online. Meanwhile, the control group students were guided to create a mind map on paper. The next step in this pre-task phase was the teacher guided the students in planning to perform the task including time allotments, processes that the students should follow, whether the task should be done individually, in pairs, or group.The second phase was During-task phase. In this phase, the students started to perform the task. The students from both experimental and control groups watched the videos on youtobe/read passages online. After they got information related to the topic that they had, students created a mind map to brainstorm the ideas. The experimental group students were creating an online mind map, while the control group students were creating a mind map on paper. Next, the students from the experimental group wrote their draft in Microsoft Word on their mobile phone, while the students from the control group wrote their draft on the paper. Having finished with their draft, the students shared their draft to get some feedback. Students in the experimental group shared their drafts in the online group, while students in the control group wrote their drafts on the paper. Then, the students developed their draft into a text and paid attention to the feedback given by their friends. The experimental group students then checked the spelling, grammar, and sentence structure by using Grammarly application through their mobile phone. After that, they revised and editted their writing based on the Grammarly result. Meanwhile, the control group students directly moved to the editing and revising phase. They should reread their writing. On one hand, students from the experimental group sent their writing to the teacher through email and published their writing on their own Instagram so that others had a chance to read their writing. On the other hand, the students from the control group needed to read their writing in front of the class before they submitted their writing to the teacher. The last phase was Post-task phase. In this phase, the students told others in front of the class how they finished their task. They needed to reflect on what they have learned when they performed the writing task. The last, they focused on forms and practicing the language (drills).

The treatments were conducted eight times, which consisted of seven meetings for the treatment and the last one meeting was for conducting the post-test. The data of this study were gathered in the form of a writing test and questionnaire. The post-test was conducted in order to know the students' writing competency, meanwhile the questionnaire was distributed in order to get the data in terms of students' motivation in writing after receiving the treatment.

The obtained data in the form of writing scores and questionnaire results were analyzed descriptively and inferentially. The descriptive statistics was used to measure the mean and the standard deviation. Before continuing to the inferential statistics, a prerequisite analysis was carried out to make sure the data were homogeneous and normally distributed. Furthermore, the data were analyzed inferentially in the form of ANOVA and MANOVA. 
ANOVA was administered to analyze the significant effect of mobile-assisted task-based on students' writing competency and students' motivation in writing. Moreover, MANOVA was administered to know the simultaneous effect of mobile-assisted task-based learning on students' writing competency and students' motivation in writing. Further, the effect size test was carried out to know the level of effectiveness of the treatment.

\section{Result}

The data obtained from the writing post-test and questionnaire were first analyzed descriptively. The result of descriptive analysis is presented in Table 1.

Table 1. Result of Descriptive Analysis

\begin{tabular}{ccccc}
\hline & \multicolumn{2}{c}{ Writing Test } & \multicolumn{2}{c}{ Questionnaire on Motivation } \\
\cline { 2 - 5 } Statistics & $\begin{array}{c}\text { Experimental } \\
\text { Group }\end{array}$ & $\begin{array}{c}\text { Control } \\
\text { Group }\end{array}$ & $\begin{array}{c}\text { Experimental } \\
\text { Group }\end{array}$ & $\begin{array}{c}\text { Control } \\
\text { Group }\end{array}$ \\
\hline Mean & 83.77 & 79.00 & 160.17 & 132.93 \\
Median & 83.00 & 79.50 & 159.00 & 132.00 \\
Mode & 90 & 81 & 158 & 128 \\
Std. Deviation & 4.946 & 4.119 & 5.547 & 7.909 \\
\hline
\end{tabular}

Table 1 showed that there was a difference in terms of the mean score between the experimental group and the control group, based on the result of the writing test and questionnaire. The students taught by mobile-assisted task-based learning had higher writing competency than those taught by using non mobile-assisted task-based learning. The mean score of the experimental group was 83.77 , meanwhile, the mean score of the control group was 79.00. In terms of motivation in writing, the mean score of the experimental group was 160.17 , and the mean score of the control group wass 132.93. This mean score indicated that the experimental group obtained higher motivation than the control group.

Before conducting the inferential statistics analysis, a prerequisite analysis was administered. The result of the normality test, the Kolmogorov-Smirnov indicated that the Sig. value for all groups was higher than .05 (Sig. $=.200)$. Furthermore, these significant results indicated that the writing competency score and motivation in writing score of all groups were from the population which was normally distributed. Therefore, the next step of data analysis could be conducted. The next prerequisite test was a homogeneity test. The result of the Levene Statistics revealed that all significant values of each group were greater than .05, which means that the variances for the four groups were equal. The Sig. value of writing competency score was .177, and the motivation in writing was .218. It was assumed that the data of writing competency and motivation in writing were homogeneous.

Therefore, inferential statistics analysis in terms of ANOVA could be further conducted. In order to be able to hold a MANOVA test, homogeneity of variance/covariance matrix test was administered. The result of the analysis showed that the value of Box's $M$ was 5.598 with Sig. value .145. It means that the value of Box's M obtained was not significant since the significant value was higher than .05. It can be concluded that the variance/covariance matrix of the dependent variables was same. Therefore, a MANOVA test could be continued.

The first research question is to investigate the significant effect of mobile-assisted task-based learning on the eleventh-grade students' writing competency, One-way ANOVA analysis was administered by using SPSS 22.0. The summary of output testing by One-way ANOVA analysis is presented in Table 2.

Table 2. Result of ANOVA Test for Writing Test

\begin{tabular}{lccccc}
\hline \multicolumn{1}{c}{ Students' Writing } & Sum of Squares & df & Mean Square & F & Sig. \\
\hline Competency Score & 340.817 & 1 & 340.817 & 16.454 & .000 \\
Between Groups & 1201.367 & 58 & 20.713 & & \\
Within Groups & 1542.183 & 59 & & & \\
Total & & & & \\
\hline
\end{tabular}


The result of the One-way ANOVA analysis for the first research question indicated that the significant value for writing test was .000 which was less than .05 . It means that the null hypothesis was rejected while the alternative hypothesis was accepted. It could be inferred that there was a significant effect of mobile-assisted task-based learning in the students' writing competency.

Furthermore, it is critical to calculate the effect size of a significant difference. In this case, the sum of squares between groups (340.817) was divided by the total sum of squares (1542.183). The result of the eta squared value was .22 which in Cohen's (1988) as cited in Pallant (2010, p. 254) was considered a large effect size. Additionally, the result of a descriptive analysis of writing competency test revealed that the mean score of students taught by using mobile-assisted task-based learning was 83.77 , while the average score of the students taught by using non-mobile-assisted task-based learning was 79.00. These findings showed that the students taught by using mobile-assisted task-based learning had better writing competency than those taught by non-mobile-assisted task-based learning.

Next, for the second research question which investigated whether there was a significant effect of mobile-assisted task-based learning on students' motivation in writing or not. The One-way ANOVA was also used to analyze the data. Table 3 presents the result of one-way ANOVA in terms of students' motivation in writing.

Table 3. Result of the ANOVA Test for Motivation Questionnaire

\begin{tabular}{cccccc}
\hline $\begin{array}{c}\text { Students' Motivation } \\
\text { in Writing Score }\end{array}$ & Sum of Squares & df & Mean Square & F & Sig. \\
\hline Between Groups & 11124.817 & 1 & 11124.817 & 238.445 & .000 \\
Within Groups & 2706.033 & 58 & 46.656 & & \\
Total & 13830.850 & 59 & & & \\
\hline
\end{tabular}

The result of the One-way ANOVA analysis indicated that the significant value for students' motivation questionnaire was .000 which was less than .05 . It means that the null hypothesis was rejected and the alternative hypothesis was accepted. It could be inferred that there was a significant effect of mobile-assisted task-based learning in the students' motivation in writing.

Furthermore, it is critical to calculate the effect size of a significant difference. In this case, the sum of squares between groups (11124.817) was divided by the total sum of squares (13830.850). The result of eta squared value is .80 which in Cohen's (1988) as cited in Pallant (2010, p. 254) was considered a large effect size.

Referring to the descriptive analysis of students' motivation in writing which revealed that the mean score of the experimental group taught by mobile-assisted task-based learning was 160.17 , while the average score of the control group taught by non-mobile-assisted taskbased learning was 132.93. This finding indicated that the experimental group students had a better motivation in writing rather than those taught by non-mobile-assisted task-based learning.

In order to answer the third research question, a MANOVA test was conducted in order to see the simultaneous effect of mobile-assisted task-based learning on eleventh-grade students' writing competency and students' motivation in writing. The summary of output testing by MANOVA analysis is presented in Table 4. 
Table 4. Result of MANOVA analysis

\begin{tabular}{llccccc}
\hline \multicolumn{7}{c}{ Multivariate Tests $^{\mathrm{a}}$} \\
\hline Effect & & Value & $\mathrm{F}$ & Hypothesis df & Error df & Sig. \\
Intercept & Pillai's Trace & .999 & $21009.879^{\mathrm{b}}$ & 2.000 & 57.000 & .000 \\
& Wilks' Lambda & .001 & $21009.879^{\mathrm{b}}$ & 2.000 & 57.000 & .000 \\
& Hotelling's Trace & 737.189 & $21009.879^{\mathrm{b}}$ & 2.000 & 57.000 & .000 \\
& Roy's Largest Root & 737.189 & $21009.879^{\mathrm{b}}$ & 2.000 & 57.000 & .000 \\
Class & .809 & $120.430^{\mathrm{b}}$ & 2.000 & 57.000 & .000 \\
& Pillai's Trace & .191 & $120.430^{\mathrm{b}}$ & 2.000 & 57.000 & .000 \\
& Wilks' Lambda & 4.226 & $120.430^{\mathrm{b}}$ & 2.000 & 57.000 & .000 \\
& Hotelling's Trace & $120.430^{\mathrm{b}}$ & 2.000 & 57.000 & .000 \\
\hline & Roy's Largest Root & 4.226 & 1200 & & &
\end{tabular}

a. Design: Intercept + Class

b. Exact statistic

The result of the analysis revealed that there was a simultaneous effect of mobileassisted task-based learning on students' writing competency and students' motivation in writing which can be seen as the significant value was lower than .05.

\section{Discussion}

The result of the One-way ANOVA analysis for the first research question as presented in Table 2 indicated that the significant value for writing test was .000 which was less than .05. It can be inferred that there was a significant effect of mobile-assisted task-based learning in the students' writing competency, with the eta squared value is .22 which is considered a large effect size. Additionally, the result of a descriptive analysis of the writing competency test revealed that the mean score of students from the experimental group was 83.77, while the average score of the control group students was 79.00 . These findings showed that the students taught by using mobile-assisted task-based learning had better writing competency than those taught by non-mobile-assisted task-based learning.

The first explanation for the critical result is that in this current study the task-based learning was implemented with the support of mobile learning. The students were allowed to use their own mobile devices in completing the task. The use of mobile devices as students' assistance in performing the task gives many benefits for the students. This finding is supported by Yedla (2013), that the use of mobile technology in the classroom creates a more interactive, innovative, and interesting classroom situation. Thus, the learning process becomes more effective as the students might search related material with the lesson on the internet and the students engaged in the learning process. In helping the students to produce effective writing, there are several mobile applications that could be accessed through students' mobile devices which were used for practicing writing. This is supported by Jati (2018) that technology has provided abundant resources for practicing language skills, in this case, is writing.

In this study, the students were allowed to find some information through watching videos on YouTube and searching related articles on a search engine such as Google. The students then created a mind map to help them in organizing their ideas. In this study, the students were asked to create a mind map on an online mind mapping tool. The MindMeister was used, it is a web-based mapping tool application. The use of online mind mapping is supported by (Ningrum et al., 2016) that the use of online mind mapping makes the students easier in making the map, reviewing, revising, and saving the map due to it is connected to students' Google drive. The use of an online mind map gives a significant effect on the students' writing as it provides the students with a more beautiful mind map, and there are many colors and shapes that can be used by the students. This is also affirmed by Budd (2004) who pointed out that the use of photos, icons, tags, and other visuals on the online mind map is useful as it allows students to interact more interestingly. Thus, the online mind map makes it faster and easier to construct mind maps.

For the next step, the students needed to develop their ideas into the paragraph. The students were required to type their writing on Ms. Word. Having finished with the writing, the 
students then shared their writing in an online group discussion. After the students finished revising their writing based on the suggestions and feedback, the students then moved to the editing phase in which they focused on grammar, spelling, punctuation, and capitalization. In order to make the students easier in editing their writing, the students were introduced to a grammar checker application, Grammarly. In this application, the students were allowed to check the grammar used, spelling, article, and the word choices. Grammarly helps the students to produce more readable and precise writing. Lee and Kim (2013) agree that applying mobile-based learning, especially in terms of grammar checkers, can improve the students' writing as it provides the students with correction on grammar mistakes, spelling, conjugation, irregular verbs, article usage, and synonyms. Therefore, the tool used to check grammar is effective in improving the students' grammar at the sentence level, as well as their writing. Moreover, AbuSa'aleek (2014) also strengthens that students who use online grammar checkers to learn writing skills are generally more able to improve editing and writing skills because they have access to give feedback on their grammar, style, and spelling errors. Therefore, the support of mobile devices and applications in the implementation of task-based learning helps the students in improving their writing skills in terms of organization of ideas, the content of the writing, sentence structure, vocabulary choices, as well as writing mechanics. It is also emphasized by Kafipour et al., (2018), Li and Hegelheimer (2013), Sundari et al., (2018) who found in their research that the presence of mobile applications in writing activity helps the students to have a better self-editing progress in terms of sentence structure, language use, vocabulary, the content of the writing, organization of the ideas, as well as the writing mechanics.

The result of the One-way ANOVA analysis for the second research question indicated that the significant value for students' motivation questionnaire was .000 which was less than .05. which means that there was a significant effect of mobile-assisted task-based learning in the students' motivation in writing, with the eta squared value is .80 and is considered a large effect size. The mean score of the experimental group who was taught by mobile-assisted task-based learning was 160.17 , while the average score of the control group taught by nonmobile-assisted task-based learning was 132.93. This finding indicated that the experimental group students had a better motivation in writing rather than those taught by non-mobileassisted task-based learning. Students' motivation in writing is affected by several factors, namely self-efficacy belief, writing task value and interest, and goal orientation (Boscolo \& Hidi, 2007; Troia et al., 2012). The first factor that affects students' motivation in writing is the presence of mobile devices applications to help the students in enhancing their self-efficacy belief. Self-efficacy is related to the students' ability in generating and ordering ideas, using correct spelling, punctuation, capitalization, and grammar (Bruning et al., 2013). The use of an online mind map helps the students in creating the mind map easier, less time consuming, and attract students' interest as they were provided with color choices, many kinds of shapes, and easy to be accessed everywhere because it is connected to students' drive. The online mind map is a productive way to engage the students' interest, encourage creativity, gain more comprehension of the topic, and get an in-depth understanding of the writing topic (Budd, 2004; Ningrum et al., 2016). Being compared with creating mind maps on paper by hands, it can consume too much time, material, and effort while an online mind mapping tool helps the students to create the map faster and easier (Budd, 2004). Karim, Abu, and Khaja (2017) point out that integrating mobile learning and online mind mapping can enhance the students' motivation and enhancing the students' writing process. In this study, Grammarly that was used as the grammar checker application helps the students to check their incorrect grammar, misspelling, vocabulary choices, and mechanics (Lee \& Kim, 2013; Li \& Hegelheimer, 2013). As can be seen in students' writing, it was found that experimental group students have fewer grammar mistakes than students from the control group. Thus, it can be said that the applications used in this study enhance the students' selfefficacy belief, especially in writing. This is confirmed by Malekzadeh and Najmi (2015) that the support of mobile devices and the applications helps the students to have better selfefficacy belief. 
The second factor is the presence of mobile devices helps the students to put their interest in the task given. Anwar and Husniah (2016) assert that utilizing mobile devices as a medium in the learning process might reduce anxiety in learning. As the students' anxiety decreased, the students could enjoy the learning process and put more interest in the activities and the task given. Moreover, combining task-based learning with mobile-assisted brings a positive impact to the students in enhancing their motivation in writing since it promotes an enjoyable learning environment where the students are offered with opportunities in several activities and use their abilities in performing the task, that affecting on students' interest (Lap \& Trang, 2017). In task-based activities, the students are encouraged to accomplish the task which is interesting and challenging enough to motivate the students to take a risk, make efforts, and take responsibility for completing the task (Anwar \& Husniah, 2016). In this study, it was observed that the students were likely engaged in the activities as they had a chance to share their ideas, knowledge, and thoughts, which could motivate them to take a part in the learning process. The task in this study was designed to make the students be able to express their ideas into written form. The task of task-based learning should be meaningful. Encouraging the students' active participation in the learning process increases their motivation. Working towards personally meaningful, challenging but achievable tasks enhance the students' motivation (Thanh \& Huan, 2012).

The last factor that affects the students' motivation was a sense of achieving their goal. In this study, the students were required to post their writing in their social media account, as they finished posting their writing on their social media, it gave them a sense of success through completing the task. The students were motivated when they actively involved and took a part in the task-based activities because the activities might satisfy their psychological needs, such as achieving the task outcome (Ryan \& Deci, 2017). Moreover, Willis \& Willis (2007) state that the students' motivation increases when they have a sense of success in achieving something or completing the assigned task. They strive to accomplish the task because they wish to be appreciated by the teacher and their classmates. Once the students are satisfied with their achievement, they then have better self-confidence and a sense of competence, which are considered as the essential factors of motivation (Ryan \& Deci, 2017). Therefore, it can be concluded that students' motivation affected the students' success in completing the task. It is reinforced by Aprizawati (2017) and Hamidun, Hashim, and Othman (2012) who agree that motivation plays an important role in the development of the students' writing and task completion, as it foster the students to write meaningfully.

The result of MANOVA analysis revealed that there was a simultaneous effect of mobile-assisted task-based learning on students' writing competency and students' motivation in writing which can be seen as the significant value was lower than .05. Kukulska-hulme and Shield (2008) point out that mobile devices enable new ways of learning, emphasize continuity and interaction, give a sense of flexibility and compatibility with the students' needs, as mobile devices provide students with essential features such as portability, social interactivity, context sensitivity, connectivity, and individuality along with numerous applications. The features of mobile devices and its applications which are used in helping the students to perform the task simulated the students' self-efficacy beliefs (Malekzadeh \& Najmi, 2015), students' interest (Lap \& Trang, 2017), the importance of task for them (Thanh \& Huan, 2012), and their goal orientation (Willis \& Willis, 2007). In other words, it fosters the students' motivation. Once the students are motivated, they can complete the given task or goals easily, they participate actively in the activities and use their ability maximumly to complete the task and reach the goal (Ellis, 2003). As the students have a good self-efficacy belief on their writing ability, put their interest of following the task sequence, think that the task is meaningful for them, and set the goal that they have to complete the task on the assigned time, which leads to the increase in the writing competency. Henceforth, the use on mobile-assisted task-based learning simultaneously gave a significant effect on the improvement of students' writing competency as well as enhancing students' motivation in writing. 


\section{Conclusion and Suggestion}

Based on the result of the experimental study through employing post-test only control group design, implementing task-based language learning with the support of mobile devices in completing the task is proven effective in improving the students' writing competency, and also enhancing the students' motivation in writing on the eleventh-grade students. Referring to the result of the One-way ANOVA analysis, there is a significant effect of mobile-assisted task-based learning on the students' writing competency and there is a significant effect of mobile-assisted task-based learning on the students' motivation in writing. Implying with the analysis of the MANOVA test, there is a simultaneous effect of mobile-assisted task-based learning on students' writing competency and students' motivation in writing.

Reflecting on the implementation and the result of the study, combining a mobile device is recommended for a teacher especially for teaching writing as an alternative strategy. It is expected to be used as another choice of giving students' experience in writing activities and other lessons in English.

\section{Acknowledgment}

The writers send their greatest gratitude to academic supervisors and lecturers at the study program of English Education who provided information, insight, expertise and great supports during the process of writing this article. The writers would also like to show gratitude to everyone who has encouraged and supported thoroughly in writing this article.

\section{References}

AbuSa'aleek, A. O. (2014). A Review of Emerging Technologies: Mobile Assisted Language Learning (MALL ). Asian Journal of Education and E-Learning, 2(06), 469-475.

Anwar, K., \& Husniah, R. (2016). Evaluating Integrated Task-Based Activities and ComputerAssisted Language Learning (CALL). English Language Teaching, 9(4), 119. https://doi.org/10.5539/elt.v9n4p119

Aprizawati. (2017). Students ' Motivation on Writing Hortatory Exposition by Using Pow Plus Tree Strategy at Sman1 Bukit Batu. Inovish Journal, 2(1), 35-47.

Arvanitis, P., Krystalli, P., \& Panagiotidis, P. (2016). Applications for Mobile Assisted Language Learning: A Current Field Research. In Proceedings of INTED2016 Conference (pp. 7645-7651).

Bipinchandra, J. S. S., Puteh, S. N., Shah, P. M., \& Din, R. (2014). User Needs Analysis in Learning Argumentative Writing Via Mobile Platform User Needs Analysis in Learning Argumentative Writing via Mobile Platform. Procedia - Social and Behavioral Sciences, 118, 198-205. https://doi.org/10.1016/j.sbspro.2014.02.027

Boscolo, P., \& Hidi, S. (2007). The Multiple Meanings of Motivation to Write. Studies in Writing, 19(2), 1-14.

Brown, H. D. (2007). Principles of Language Learning and Teaching (Fifth Edit). New York: Pearson Longman.

Bruning, R., Dempsey, M. S., Kauffman, D. F., \& Zumbrunn, S. (2013). Examining Dimensions of Self-Efficacy for Writing. Journal of Educational Psychology, 105(1), 2538. https://doi.org/10.1037/a0029692

Budd, J. W. (2004). Mind Maps as Classroom Exercises. Journal of Economic Education, 35(1), 35-46.

Dost, I. N., Bohloulzadeh, G., \& Pazhakh, A. (2017). The Effect of Task-Based Language Teaching on Motivation and Grammatical Achievement of EFL Junior High School Students. Advances in Language and Literary Studies, 8(2). https://doi.org/10.7575/aiac.alls.v.8n.2p.243

Dwivedi, R. S. (2015). Problems Encountered By Rural Students in Writing English - Role of English Teacher - Some Solutions, 3(7), 27-38.

Ellis, R. (2003). Task-Based Language Learning and Teaching. Oxford: Oxford University Press. 
Estarki, N. K., \& Bazyar, M. (2016). The Effect of MALL on Pre-intermediate EFL Learners' Writing Performance. European Online Journal of Natural and Social Sciences, 5(2), 406-420.

Gupta, D., \& Woldemariam, G. S. (2011). The Influence of Motivation and Attitude on Writing Strategy Use of Undergraduate EFL Students: Quantitative and Qualitative Perspectives. The Asian EFL Journal Quarterly, 13(2), 34-89.

Hamidun, N., Hashim, S. H., \& Othman, N. F. (2012). Enhancing Students 'Motivation by Providing Feedback on Writing: The Case of International Students from. International Journal of Social Science and Humanity, 2(6), 2-5. https://doi.org/10.7763/IJSSH.2012.V2.179

Harmer, J. (2004). How to Teach Writing. Malaysia: Pearson Longman.

Huang, D. (2016). A Study on the Application of Task-based Language Teaching Method in a Comprehensive English Class in China. Journal of Language Teaching and Research, 7(1), 118. https://doi.org/10.17507/jltr.0701.13

Jati, A. G. (2018). The Use of Smartphone Applications in English Language Teaching and Learning. Jurnal Sosioteknologi /, 17(2), 144-153.

Kafipour, R., Mahmoudi, E., \& Khojasteh, L. (2018a). The Effect of Task-Based Language Teaching on Analytic Writing in EFL Classrooms. Cogent Education, 5(1), 1-16. https://doi.org/10.1080/2331186X.2018.1496627

Karim, R. A., Abu, A. G., \& Khaja, F. N. M. (2017). Theoretical Perspectives and Practices of Mobile-Assisted Language Learning and Mind Mapping in the Teaching of Writing in ESL Classrooms. Journal of English Teaching Adi Buana, 02(01), 1-12.

Kukulska-hulme, A., \& Shield, L. (2008). An Overview of Mobile Assisted Language Learning: From Content Delivery to Supported Collaboration and Interaction. ReCALL, 20(3), 271-189. https://doi.org/10.1017/S0958344008000335

Lap, T. Q., \& Trang, H. D. (2017). The Effect of Task-Based Learning on EF Students' Learning Reading: A Case Study in the Mekong Delta of Vietnam. Studies in English Language Teaching, 5(1), 34-48. https://doi.org/10.22158/selt.v5n1p34

Lee, K. J., \& Kim, J. E. (2013). A Mobile-based Learning Tool to Improve Writing Skills of EFL Learners. Procedia - Social and Behavioral Sciences, 106, 112-119. https://doi.org/10.1016/j.sbspro.2013.12.014

Li, Z., \& Hegelheimer, V. (2013). Mobile-Assisted Grammar f-Exercises: Effects on SelfEditing in L2 Writing. Language Learning \& Technology, 17(3), 135-156.

Lincoln, F., \& Idris, A. Ben. (2015). Teaching the Writing Process as a First and Second Language Revisited: Are They the Same? Journal of International Education Research, 11(2), 119-124. https://doi.org/10.19030/jier.v11i2.9192

Linse, C., \& Nunan, D. (2005). Practical English Language Teaching: Young Learners. New York: McGraw-Hill.

Listyani. (2018). Promoting Academic Writing Students' Skills through "Process Writing" Strategy. Advances in Language and Literary Studies, 9(4), 173-179.

Malekzadeh, R., \& Najmi, K. (2015). The Effect of Mobile-Assisted Language Learning (MALL) on Guided Writing Skills of Iranian Upper-Intermediate EFL Learners. Journal of Applied Linguistics and Language Research, 2(4), 42-52.

Marashi, H., \& Dadari, L. (2012). The Impact of Using Task-based Writing on EFL Learners' Writing Performance and Creativity. Theory and Practice in Language Studies, 2(12), 2500-2507. https://doi.org/10.4304/tpls.2.12.2500-2507

Miangah, T. M., \& Nezarat, A. (2012). Mobile-Assisted Language Learning. International Journal of Distributed and Parallel Systems, 2019 (February 2015), 309-319. https://doi.org/10.5121/ijdps.2012.3126

Naqbi, S. Al. (2011). The use of mind mapping to develop writing skills in UAE schools. Education, Business and Society: Contemporary Middle Eastern Issues, 4(2), 120-133. https://doi.org/10.1108/17537981111143855

Ningrum, A. S. B., Latief, M. A., \& Sulistyo, G. H. (2016). The Effect of Mind Mapping on EFL Students ' Idea Development in Argumentative Writing across Gender Differences and Learning Styles. Dinamika IImu, 16(1), 149-166. 
Park, M., \& Slater, T. (2014). A Typology of Tasks for Mobile-Assisted Language Learning: Recommendations from a Small-Scale Needs Analysis. TESL Canada Journal, 31(8), 93-115.

Reichelt, M. (2005). WAC Practices at the Secondary Level in Germany. The WAC Journal, 16, 89-100.

Richards, J. C., \& Rodgers, T. S. (2001). Approaches and Methods in Language Teaching (5th Edition). New York: Cambridge University Press.

Ryan, R. M., \& Deci, E. L. (2017). Self-Determination Theory: Basic Psychological Needs in Motivation, Development, and Wellness. New York: The Guilford Press.

Sundari, H., Febriyanti, R. H., \& Saragih, G. (2018). Using Task-based Materials in Teaching Writing for EFL Classes in Indonesia. International Journal of Applied Linguistics \& English Literature, 7(3), 119-124.

Thanh, L. N., \& Huan, N. B. (2012). Task-Based Language Learning and Student Motivation in Vocabulary Acquisition. Language Education in Asia, 3(1), 106-120.

Thomas, M., \& Reinders, H. (2010). Task Based Language Learning and Teaching with Technology. New York: Continuum.

Troia, G. A., Shankland, R. K., \& Wolbers, K. A. (2012). Motivation Research in Writing: Theoretical and Empirical Considerations Authors. Reading \& Writing Quarterly, 28(1), 5-28. https://doi.org/10.1080/10573569.2012.632729

Willis, D., \& Willis, J. (2007). Doing Task-Based Teaching (Oxford Handbooks for Language Teachers). New York: Oxford University Press.

Yedla, S. (2013). MALL : A Paradise for English Language Learners MALL (Mobile Assisted Language Learning): A Paradise for English. International Journal of English Language \& Translation Studies, I(2), 91-99.

Yudhiantara, R. A., \& Sugilar, H. (2018). Menuju Implementasi Mobile Assisted Language Learning (MALL): Penggunaan SmartPhone Untuk Pembelajaran Kamus Monolingual Bahasa Inggris. Jurnal Perspektif, 02(01), 68-78.

Ziegler, N. (2016). Taking Technology to Task: Technology-Mediated TBLT, Performance, and Production. Annual Review of Applied Linguistics, 36, 136-163. https://doi.org/10.1017/S0267190516000039 